\title{
Analysis of Myenteric Neurons of the Cecum of Diabetic Rats After Supplementation with Ascorbic Acid
}

\author{
Análisis de Neuronas Mientéricas del Ciego de Ratas Diabéticas \\ Después de Suplementación con Ácido Ascórbico
}

Jacqueline Nelisis Zanoni; Priscila Gonçalves Cardoso Pereira \& Marli Aparecida dos Santos Pereira

ZANONI, J. N.; PEREIRA, P. G. C. \& DOS SANTOS, M. A. Analysis of myenteric neurons of the cecum of diabetic rats after supplementation with ascorbic acid. Int. J. Morphol., 27(2):387-392, 2009.

SUMMARY: The objective of this work was to investigate the neuroprotective action of the ascorbic acid over the myenteric neurons in the cecum of Wistar rats, four months after induction of the diabetes mellitus experimental with streptozotocin. Three groups with five rats each were used: C- controls, D- diabetic, DA- diabetic treated with ascorbic acid. For evidentiation of the myenteric neurons was carried out to Giemsa's technique. Were evaluated the areas of cell bodies of 500 neurons in each group studied. The quantitative analysis was carried out in an area of $16.6 \mathrm{~mm} 2$ in each cecum studied. In the animals diabetic observed elevation of the glycemia and glycated hemoglobin. The supplementation with ascorbic acid was effective under the myenteric neurons of the cecum of diabetics rays, since was presented the effect neuroprotective and neurotrofic.

KEY WORDS: Ascorbic acid; Diabetes mellitus; Oxidative stress; Cecum; Streptozotocin.

\section{INTRODUCTION}

The diabetes mellitus is one of the chronic illnesses more diffused in the world (Booya et al., 2005). Several are the alterations provoked by the diabetes mellitus, among them shine through the neuropathy, however the mechanisms that generate the wounds in the nerves still do not be completely understood and explored.

Due to the physiology of the diabetes mellitus the gastrointestinal tract intensely is attacked, are observed big enlargement of the stomach, small and large intestines (Diane et al., 1979; Zanoni et al., 1997; 2003). The manifestations observed in gastrointestinal tract are generated mainly due to the neurological alterations that are located in particular in the Autonomic Nervous System (Hosking et al., 1978).

The neuronal damage due to diabetes mellitus has been attributed mainly to sorbitol, a polyol synthesized from the glucose reduction by the aldose reductase (Vinson et al., 1989). The sorbitol is transformed into fructose and they both, in high concentrations, cause an increase of intracellular osmolality with edema formation, neuronal lesion and a consequent reduction of the nervous conduction speed (Silva $\&$ Teixeira, 1999). The free radicals are also responsible for provoking neuronal damage due to the increase of the oxidative stress (Kuyvenhoven \& Meinders, 1999) because of an increase of the non-enzymatic glycosylation, increase of the auto oxidation, increase of the metabolic stress, reduction of the levels of antioxidant as, by example, the acid ascorbic (Young et al., 1992). Therefore, they are involved in reactions that can cause irreversible damages to the cells such as loss of cellular function and death by necrosis or apoptosis (Hirotaka \& Yasuhito, 2002).

The diabetes mellitus provokes death of the myenteric neurons, as shown by the reduction in their number and alteration in their size, after long periods of diabetes, in several intestinal segments (Romano et al., 1996; Zanoni et al., 1997, 2003; Hernandes et al., 2000; Fregonesi et al., 2005).

Drugs that reduce the concentration of sorbitol and the oxidative stress are prominent in the treatment of the chronic complications of the diabetes mellitus, being that the acid ascorbic is some of these substances, therefore acts in the inhibition of the enzyme aldose reductase, responsible by the reduction of the glucose in sorbitol, and also in the 
reduction of the species reactivate to the oxygen, suggesting a prominent paper in the neuroprotection (Yue et al., 1989; Cunningham et al., 1994; Cunningham, 1998; Will \& Byers, 1996).

Thus, the purpose of this work was to determine the neuroprotective effect of ascorbic acid about the density and size of myenteric neurons in the cecum of diabetic rats.

\section{MATERIAL AND METHOD}

Animal procedures. All experiments described in this work are according to the ethical beginnings adopted by the Brazilian College of Animal Experimentation (COBEA), and were supervised and approved by the Committee of Ethics on Animal Experimentation of the State University of Maringá.

Fifty male Wistar rats (Rattus norvegicus), 90 days of age, were used. The rats were divided into three groups: untreated controls (C), untreated diabetes (D) and diabetes treated with ascorbic acid (DA). Diabetes mellitus was induced through intravenous administration of streptozotocin (35 mg/kg body weight; Sigma, St. Louis, MO, USA), dissolved in a $10 \mathrm{mM}$ citrate buffer solution $(\mathrm{pH} 4.5)$, after a 14-hr fast. The animals were kept in individual cages, receiving water and food (Nuvital lab) ad libitum, with a controlled photoperiod (06:00-18:00 hr) and room temperature $\left(24^{\circ} \mathrm{C} \pm 2^{\circ} \mathrm{C}\right)$.

Ascorbic acid (Sigma, St. Louis, MO, USA) was added daily to the animal's water from DA group for four months (1 g/L prepared fresh each day) $(133.6 \mathrm{mg} / \mathrm{ml})$ (Young et al.). The amounts of food intake, water consumption, and eliminated urine were measured during the treatment of rats.

At 210 days of age the animals were anesthetized with thiopental (40 mg/kg body weight). Blood was collected by cardiac puncture to measure the blood levels of glycemia, glycated hemoglobin and ascorbic acid.

Subsequently, the cecum were washed with saline solution and filled with fixing solution of Giemsa respecting the physiology of the organ, therefore without occur distensions. Right away the body was dissected under stereomicroscopy and stained according to the technical of Giemsa for evidentiation of the myenteric neurons (Barbosa, 1978).

Quantitative analysis of myenteric neurons. The cell bodies of the myenteric neurons of cecum were counted in microscope of light, with a 40x objective lens. The quantification was carried out by sample in the two thirds near to the antimesocolic region utilizing Olympus BX50 microscope. In each segment of each animal were counted 102 fields. The area of the field of the microscope was measured with a micrometered ruler Zeiss. The results were expressed as neurons by $\mathrm{mm}^{2}$. The total area quantificated was of $16.6 \mathrm{~mm}^{2}$.

Size of cecum and calculation for enlargement proportion obtaining of cecum of diabetic rats (group D and DA).

The results obtained for the neuronal quantification should be corrected, since alterations in the size of the intestine, provoked by the intestinal growth with the natural ageing process and/or by pathological process, are able to "dilute" the number of present neurons in the area analyzed (Cowen et al., 2000).

The cecum was collected and positioned about sulfite white paper and the contours of the longitudinal average section was carried out through tracing, for obtaining of the circumference of the area of the cecum $\left(\mathrm{mm}^{2}\right)$. The area was obtained through images analysis software Image Pro Plus 4 (Average Cybernetics, USA) (Table I). To the correction of the neuronal density was calculated the proportion of the dilatation of the cecum of groups D and DA in relation the group C, where quantitative results were multiplied.

Morphometric analysis. The images were obtained with a high-resolution, transmitted to a microcomputer and recorded into a compact disc. The cell body area $\left(\mu \mathrm{m}^{2}\right)$ of 100 cell bodies in each animal, in a total of 500 neurons for each group studied was measured through images analysis software Image Pro Plus 4 (Average Cybernetics, USA).

Statistical analysis. Results were subjected to statistical analyses through the programs Statistica and GraphPad Prism, being expressed as media \pm standard error. Morphometric data were set in delineation blocks followed by Tukey's test. For the other results, we used the variance analysis One-way ANOVA, followed by Tukey's test. Significance level was set at $5 \%$.

\section{RESULTS}

The streptozotocin promoted to diabetic syndrome in the animal of the group D and DA, therefore all of the rats were severely hyperglycemia shown up by the blood glucose 
levels and rate of glycated haemoglobin $(\mathrm{p}<0.05)$ (Fig. 1). Also they were observed hyperfagia, polydypsia, polyuria (Figure 1). The plasma level of ascorbic acid in the groups C, D and DA were, respectively, 24.58 $\pm 5.5,12.6 \pm 1.9$ and $33.1 \pm 2.5, \mathrm{p}>0.05$ when the group $\mathrm{C}$ is compared with group D and DA and $\mathrm{p}<0.05$, when the group $\mathrm{D}$ is compared with group DA. The medium initial weight of the rats of the groups $\mathrm{C}, \mathrm{D}$ and DA were similar $(\mathrm{p}>0.05)$ (Fig. 1). The animals of the groups $\mathrm{D}$ and $\mathrm{DA}$ presented a reduction of the corporal weight when compared to the group $C(p<0.05)$. However, the results of the group D and DA were similar ( $\mathrm{p}$ $>0.05)$. The circumferences of the areas and the proportion of the dilatation of cecum of diabetic animals (groups D and DA) were shown in Table I.

Table I. Area in $\mathrm{mm}^{2}$ of the circumference of the cecum of the groups controls $(\mathrm{C})$, diabetic (D) and diabetic treated with ascorbic acid. $\mathrm{n}=5$ animals by group.

\begin{tabular}{lccccc}
\hline & Area C & Area D & $\begin{array}{c}\text { Proportion } \\
\text { of the dilatation D }\end{array}$ & Area DA & $\begin{array}{c}\text { Correction } \\
\text { DA }\end{array}$ \\
\hline 1 & 808.4727 & 1006.164 & $+35.18 \%$ & 1896.535 & $+65.61 \%$ \\
2 & 538.7461 & 997.4688 & $+34.61 \%$ & 1156.453 & $+43.60 \%$ \\
3 & 614.3594 & 2088.758 & $+68.78 \%$ & 1218.938 & $+46.49 \%$ \\
4 & 493.2031 & 2103.398 & $+68.99 \%$ & 1108.738 & $+41.18 \%$ \\
5 & 806.1992 & 1417.367 & $+53.99 \%$ & 1345.166 & $+49.22 \%$ \\
$M$ & \pm & $652.2 \pm$ & $1523 \pm$ & & $1345 \pm$ \\
\end{tabular}

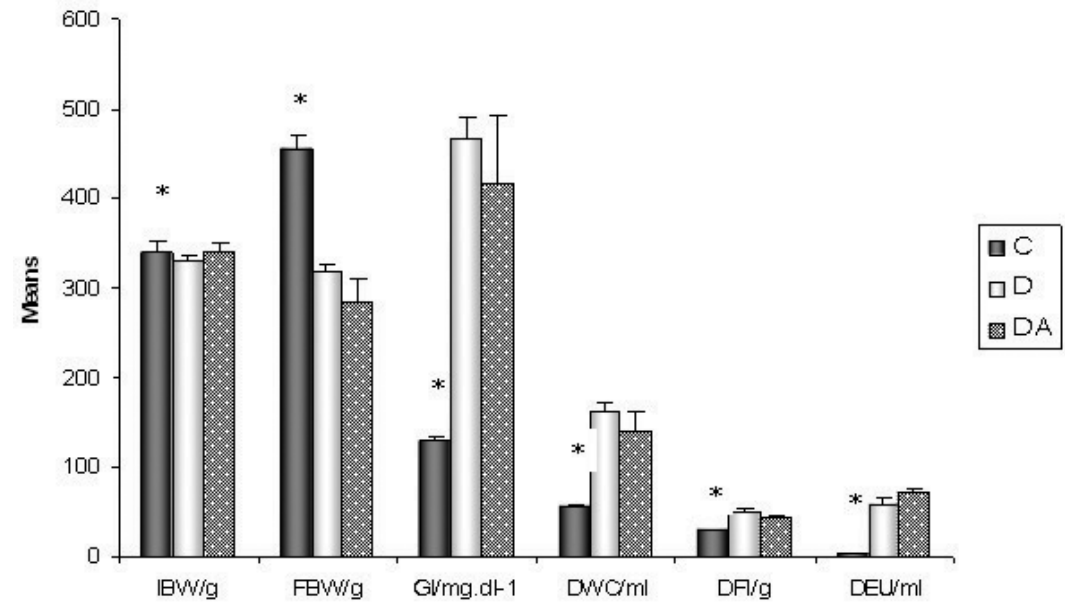

Fig. 1. Initial body weight (IBW) and final body weight (FBW), glycemia (GI), daily water consumption (DWC), daily food intake (DFI) and daily elimination (DEU) in controls (C), diabetic (D) and diabetic treated with ascorbic acid. $\mathrm{n}=5$ animals by group. All results are mean \pm SE. $p$ $<0.05$ when compared with D and DA group $(\mathrm{p}<0.05)$.

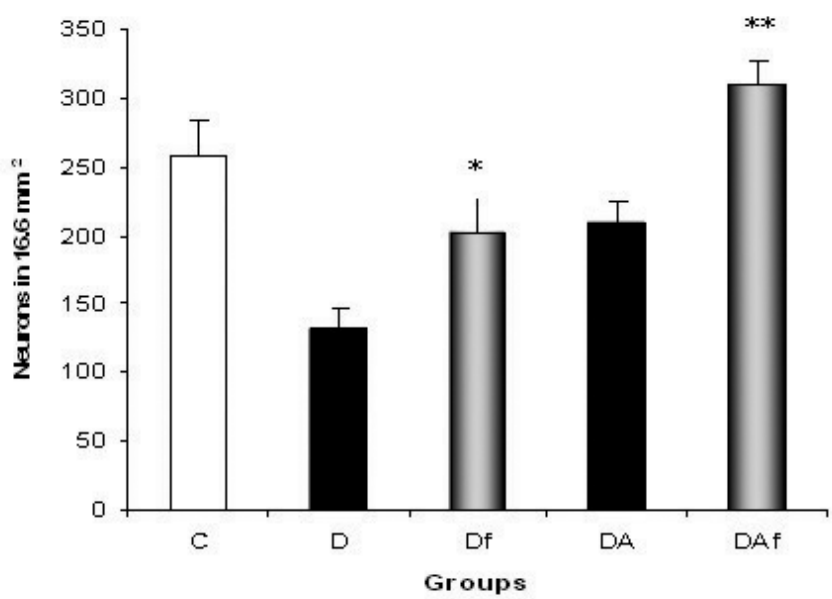

Fig. 2. Number of myenteric neurons in an area of $16.6 \mathrm{~mm} 2$ observed in the cecum of rats. Key: controls (C), diabetic (D) and diabetic treated with ascorbic acid. $\mathrm{n}=5$ animals by group. All results are mean \pm SE. $* \mathrm{p}<0.05$, compared to the corresponding values in group C. $* * \mathrm{p}<0.001$, compared to the corresponding values in group $\mathrm{D}$ and $\mathrm{p}<0.05$ compared to Df. 
The results of the neuronal quantification are shown in the Fig. 2.

The mean areas $\left(\mathrm{mm}^{2}\right)$ of groups $\mathrm{C}, \mathrm{D}$ and DA were $138.4+20.22,102.4+3.26$ and $150.9+14.20$, respectively, $p<0.05$ when all groups were compared. The majority of the neurons presented cell profiles that varied of 101 to 200 $\mathrm{mm}^{2}$. The proportion of neurons in this streak for the groups C, D and DA was of $26.43 \%, 32.89 \%$ and $40.68 \%$, respectively, as sample the Fig. 3 .

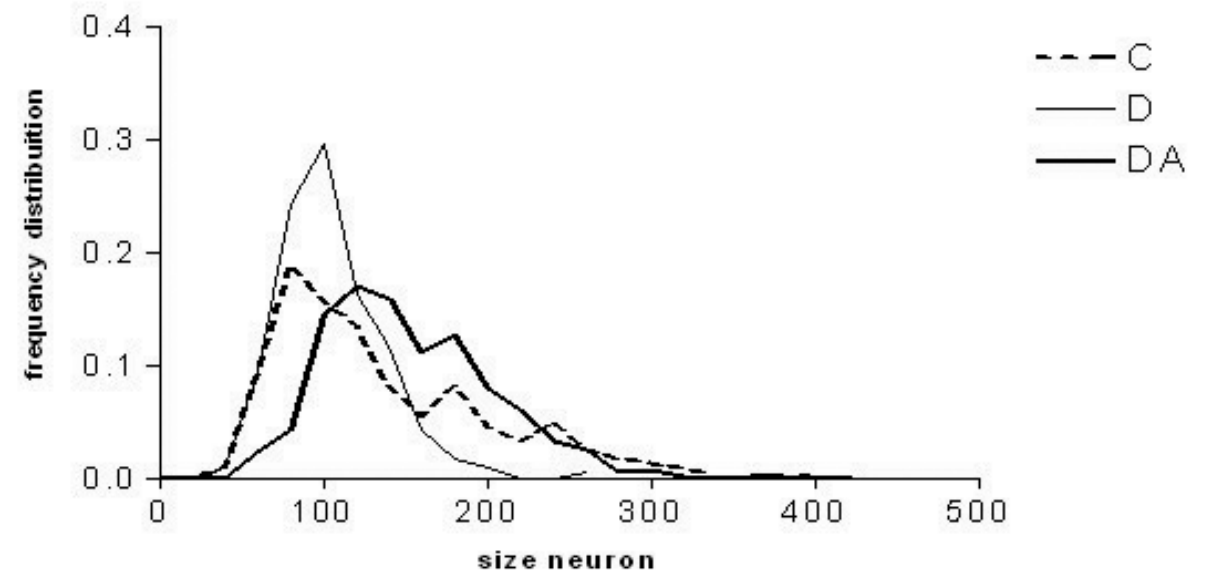

Fig. 3. Size distribution of myenteric neurons. They were classified from 100 to $500 \mu \mathrm{m}^{2}$. Key: controls (C), diabetic (D) and diabetic treated with ascorbic acid. $\mathrm{n}=5$ animals by group. All results are mean \pm SE. $* p<0.05$, compared to the corresponding values in group.

\section{DISCUSSION}

The diabetes mellitus promoted a reduction of $48.7 \%$ in the concentration of plasma level of ascorbic acid. Probably, that reduction occurs in consequence of the oxidative stress state, that promotes increase of the index of free radicals and diminution of the antioxidants substances (Kuyvenhoven \& Meinders) and a consequent increase of the amount in its utilization. Another factor that causes the reduction in the ascorbic acid levels is originated in consequence of the hyperglycemia, therefore stops his transport, as well as to its kidney reabsorption (Cunningham). And the own ageing provokes a reduction of ascorbic acid in the plasma and in the majority of the tissues (Michels \& Hagen, 2004). The supplementation with ascorbic acid was satisfactory; therefore increase its plasma concentration in $61.9 \%$ respecting the animals of the group D and $25.7 \%$ respecting the group $\mathrm{C}$.

It was verified a reduction in the neuronal density of $49.7 \%$ in the group D $\left(131.8+13.89\right.$ neurons $\left./ 16,6 \mathrm{~mm}^{2}\right)$ compared the controls $\left(258.8+24.54\right.$ neurons $\left./ 16.6 \mathrm{~mm}^{2}\right)$, our results are similar to those publicated by Zanoni et al. (1997) that showed up in cecum a reduction in the proportion of $34.6 \%$. However, when we correct the density through the area of the cecum we verify that the neuronal density in the group D was elevated in $34 \%$ in the group Df (197.6 \pm .28 .45 neurons $/ 16.6 \mathrm{~mm}^{2}$ ) The neuronal density was minor in the group D compared the group Df due to the neuronal dilution provoked by the increase of the size of cecum that vouches the importance of the correction factor calculation. We observed that even correcting the density regarding enlargement of cecum, they were lost $21.68 \%$ myenteric neurons of the diabetic animals of the medium region of cecum that assures the importance to do an supplementation with agents that prevent the development of diabetic neuropathy. The reduction in the neuronal density in the animal of the group D occurs due several factors of which is relevant the function of the sorbitol and the action of the free radicals (Kuyvenhoven \& Meinders). In the digestive system several intestinal segments are affected in consequence of the diabetic neuropathy, the reduction of the neuronal density was observed in the duodenum (Büttow et al., 1997), ileum (Zanoni et al., 2003), however the most affected is cecum where is observed a big increase of size.

In the group DA were shown up a density of $209.2 \pm$ 16.61 neurons $/ 16,6 \mathrm{~mm}^{2}$ that had a light improvement of $36.99 \%$ upon they will be compared with the group D. The correction of the area of cecum elevated the neuronal density in $57.40 \%$ in the group DAf $(300.7 \pm 16.04$ neurons/16.6 $\mathrm{mm}^{2}$ ) regarding the group $\mathrm{D}$. With these results we could infer that the supplementation with ascorbic acid in the diabetic animal had a beneficial effect because preserved 
the death of a big quantity of myenteric neurons regarding of the not supplement and consequently, this effect reflected about the smooth musculature therefore was observed a reduction of $11.7 \%$ in the size of cecum what show a better activity neuronal. Beyond it present effect neuroprotective, the ascorbic acid presented effect neurotrofic, therefore was shown up myenteric neurons of the group DA with upper areas those verified in the control group.

In conclusion, our research allows us to conclude that the ascorbic acid show effect neuroprotective and neurotrofic under the myenteric neurons of the cecum of diabetics rats.

ZANONI, J. N.; PEREIRA, P. G. C. \& DOS SANTOS, M. A. Análisis de neuronas mientéricas del ciego de ratas diabéticas después de suplementación con ácido ascórbico. Int. J. Morphol., 27(2):387-392, 2009.

RESUMEN: El objetivo de este trabajo fue verificar el efecto neuroprotector del ácido ascórbico sobre las neuronas mientéricas en el ciego de Rattus Wistar, cuatro meses después de la inducción de diabetes mellitus experimental con estreptozotocina. Utilizamos tres grupos de animales: C- control, D- diabético, DA- diabético tratado con ácido ascórbico. Para la observación de las neuronas mientéricas fue llevado a cabo la técnica de Giemsa. Fueron evaluadas las áreas del soma de 500 neuronas, en cada grupo estudiado. El análisis cuantitativo fue llevado a cabo, en cada ciego, en un área de 16,6 mm². En los animales diabéticos, se observó la elevación de la glicemia y de la hemoglobina glicosilada. La suplementación con ácido ascórbico fue efectiva en las neuronas mientéricas del ciego de animales diabéticos, ya que se produjeron los efectos neuroprotetor y neurotrófico.

PALABRAS CLAVE: Ácido ascórbico; Diabetes mellitus; Estrés oxidativo; Ciego; Estreptozotocina.

\section{REFERENCES}

Barbosa, A. J. Histological technique for intramural ganglia in thick tissue preparation. Rev. Bras. Pesqui. Med. Biol., 11(2-3):95-7, 1978.

Booya, F.; Bandarian, F.; Larijani, B., Pajouhi, M.; Nooraei, M. \& Lotfi, J. Potential risk factors for diabetic neuropathy: a case control study. BMC Neurol., 10:524, 2005.

Büttow, N. C.; Miranda Neto, M. H. \& Bazotte, R. B. Mophological and quantitative study of the myenteric plexus of the duodenum of streptozotocin-induced diabetic rats. Arq. Gastroenterol., 34(1):34-42, 1997.

Cowen, T.; Johnson, R. J.; Soubeyre, V. \& Santer, R. M. Restricted diet rescues rat enteric motor neurons from age related cell death. Gut. 47:653-60, 2000.

Cunningham, J. J. The glucose? Insulin system and vitamin $\mathrm{C}$ : implications in insulin-dependent diabetes mellitus. J. Am. Col. Nut., 17:105-8, 1998.

Cunningham, J. J.; Mearkle, P. L. \& Brown, G. Vitamin C: an aldose reductase inhibitor that normalizes erythrocyte sorbitol in insulin-dependent diabetes mellitus. J. Am. Col. Nut., 13:344-50, 1994.

Diane, A. R.; Grogan, D. M.; Yates, M. E.; Risinger, D. L. \& Gerritsen, G. C. Radiologic abnormalities and autonomic neuropathology of the digestive tract of the Ketonuric Diabetic Chinese Hamster. Diabetologia, 17:33-40,1979.
Fregonesi, C. E.; Molinari, S. L.; Alves, A. M.; Defani, M. A.; Zanoni, J. N.; Bazotte, R. B. \& de Miranda Neto, M. H. Morphoquantitative aspects of nitrergic myoenteric neurons from the stomach of diabetic rats supplemented with acetyl-L-carnitine. Anat. Histol. Embryol., 34(2):937, 2005 .

Hernandes, L.; Bazotte, R. B.; Gama, P. \& Miranda-Neto, M. H. Streptozotocin-induced diabetic duration is important to determine changes in the number and basophily of myenteric neurons. Arq. Neuropsiquiatr., 58:1035-9, 2000.

Hirotaka, I. \& Yasuhito, N. Biological significance of phospholipid hydroperoxidglutathione peroxidade (PHGPx, GPx4) in mammalian cells. Free Rad. Biol. Med., 34(2):145-69, 2002.

Hosking, D. J.; Bennett, T. \& Hampton, D. M. Diabetic Autonomic Neuropathy. Diabetes, 27(10):1043-55, 1978.

Kuyvenhoven, J. P. \& Meinders, A. E. Oxidative stress and diabetes mellitus-Pathogenesis of long-term complications. Eur. J. Inter. Med., 10:9-19, 1999.

Michels, A. J. \& Hagen, T. M. Vitamin C status declines with age. In: Asard, H.; May, J. M. \& Smirnoff, N. (Eds.). Vitamin C - Functions and biochemistry in animals and plants. London, Taylor \& Francis, 2004. pp.203-27. 
Romano, E. B.; Miranda-Neto, M. H. \& Cardoso, R. C. Preliminary investigation about the effects of streptozotocin induced chronic diabetes on the nerve cell number and size of myenteric ganglia in rat colon. Rev. Chil. Anat., 14(2):139-45,1996.

Silva, C. B. \& Teixeira, M. J. Neuropatía diabética. Rev. Med., 78:150-62, 1999.

Vinson, J. A.; Staretz, M. A; Bose, P. \& Kassm, H. M. In vitro and in vivo reduction of erythrocyte sorbitol by ascorbic acid. Diabetes, 38:1036-41, 1989.

Will, J. C. \& Byers, T. Does diabetes mellitus increase the requirement for vitamin C?. Nutr. Rev., 54(7):193-202, 1996.

Young, I. S.; Torney, J. J. \& Trimble, E. R. The effect of ascorbate supplementation on oxidative stress in the streptozotocin diabetic rat. Free Radic. Biol. Med., 13(1):41-6, 1992.

Yue, D. K.; Mclennan, S.; Fisher, E.; Heffernan, S.; Capogreco.; Roos, G. R. \& Turtle, J. R. Ascorbic acid metabolism and polyol pathway in diabetes. Diabetes, 38:257-61, 1989.

Zanoni, J. N.; Buttow, N. C. \& Miranda Neto, M. H. Evaluation of the population of NADPH-diaphorasestained and myosin- $\mathrm{V}$ myenteric neurons in the ileum of chronically streptozotocin-diabetic rats treated with ascorbic acid. Auton. Neurosci., 104(1):32-8, 2003.

Zanoni, J. N.; Miranda Neto, M. H.; Bazotte, R. B. \& Souza, R. R. Morphological and quantitative analysis of the neurons of the myenteric plexus of the cecum of streptozotocin diabetic rats. Arq. Neuropsquiatr., 55(4):696-702, 1997.
Correspondence to:

Dr. Jacqueline Nelisis Zanoni

Universidade Estadual de Maringá

Departamento de Ciências Morfofisiológicas,

Bloco H-79

Campus Universitário - Av. Colombo, 5790

CEP 87020900

Maringá, PR

BRASIL

Email.jnzanoni@uem.br

Received: 10-07-2008

Accepted: 22-01-2009 